DOI: https://doi.org/10.47405/mjssh.v6i8.962

\begin{tabular}{|c|c|}
\hline 4.581 & Malaysian Journal of Social Sciences and Humanities (MJSSH) \\
\hline $\begin{array}{l}\text { Malaysian Journal of } \\
\text { Social cciences and }\end{array}$ & Volume 6, Issue 8, August 2021 \\
\hline (MJ-SSH) & e-ISSN : 2504-8562 \\
\hline & $\begin{array}{l}\text { Journal home page: } \\
\text { www.msocialsciences.com }\end{array}$ \\
\hline
\end{tabular}

\title{
Socio-Cultural Gender Norms and Economic Barriers in The Context of Rural High School Girls' Dropout in Bangladesh: A Qualitative Study
}

\author{
Afia Arafat', Noor Azizah Ahmad', Sharifah Fazliyatun Bt Shaik Ismail² \\ 1School of Applied Psychology, Social Work and Policy, Universiti Utara Malaysia (UUM) \\ ${ }^{2}$ School of Languages, Civilization and Philosophy, Universiti Utara Malaysia (UUM) \\ Correspondence: Afia Arafat (anasuya.air27@gmail.com)
}

\begin{abstract}
While attending high schools, in Bangladesh, rural school girls face the pressure of socio-cultural gender norms and the barriers of economic deprivation. This paper aims to analyze the multifaceted connection between gender norms and economic deprivation of families in rural Bangladesh; and how the dynamics of the connection affect high school girls' opportunities of further education. The paper identifies the major factors that lead girls to drop out of school. In-depth qualitative interview sessions were conducted with 5 rural high school dropout girls. The analysis incorporates both thematic and narrative analyses. The study finds that gender norms, socioeconomic realities, deprivation and poverty work as barriers; and affect girl's future education by restricting girl's opportunities and social mobility with the support of discriminatory gender norms and practices. Parents compromise on girls' education by giving gender norms a priority. Instead of encouraging girls' future education parents tend to ensure their daughter's future in an early marriage. Among the financially challenged families, girls' domestic duties are prioritized over their aspiration of getting education. Most parents are concerned about the sexual security/chastity of their girls, which also force girls to drop out of high schools. Few parents/guardians who encourage and support girls' education usually take the initiative to bring changes by resisting social norms that obstruct and limit girls' opportunities. The paper concludes that in the context of persistent socio-cultural gender norms, resistance against regressive gender ideologies and social norms are needed to bring positive changes in gender socialization.
\end{abstract}

Keywords: socio-cultural, gender norms, economic barriers, school dropout, rural, Bangladesh

\section{Introduction}

For the sustainable development of any society, and to attain gender equality and female empowerment; a comprehensive primary and secondary education for both boys and girls is essential. (Chisamya, DeJaeghere, Kendall, \& Khan, 2012; Nations, 2015). In Bangladesh there has been considerable progress in accessing primary education, but gender disparities continue to persist and hinder in accessing secondary education in rural areas (Sarker, Karim, \& Suffiun, 2017). Adolescents (boys and girls) face the pressure of social and cultural expectations of socio-cultural gender norms and practices in their daily life, in education, and in career plans (Varga, 2003). Nevertheless, boys relatively have less social or cultural restrictions imposed on them, they rather enjoy social and cultural freedom; whereas girls are forced to be bound by strict social and cultural norms and restrictions (Jayachandran, 2021). The imposition of social, cultural and gender norms on girls limit their opportunities to be accomplished; put them in the vicious trap of early marriage, which 
eventually results in a huge number of girls' dropout from high school (Ferdousi, 2014; Sarkar, Reza, \& Hossain, 2014). Early marriage of adolescent girls, and school dropout lead to early child-bearing, which intensifies unsafe reproductive and sexual health consequences; such as higher level of maternal and infant mortality, increase in HIV and other sexual infectious diseases (Abound, 2007; Namuliira, 2020). Dropping out of school has other consequences: lower access to earning and financial stability; lower access to any decision making power in household matters and personal life; lower access to available health services: for instance reproductive and sexual (Svanemyr, Moland, Blystad, Zulu, \& Sandøy, 2021). The vicious consequences of lack of education continues to badly affect a woman's whole life, and even affect the next generation through prolong poverty and poor health. (Hunt, 2008). Gender inequality in access to (and the completion of) high school education entraps the girls in a detrimental cycles of life (Lane, Brundage, \& Kreinin, 2017).

A review of several research studies show that the reasons girls discontinue high school in rural Bangladesh are complex and multifaceted (Latif, Usman, Ali, \& Amjad, 2020). However, most of the studies conducted were quantitative studies, which leave many unanswered questions about the complex reasons for dropout. Feasible in-depth qualitative studies are suggested to research on high school dropout to understand how social and cultural gender norms, socio economic structures, financial deprivation, and discriminatory domesticity collectively function to deprive young girls from high school education (Ramsdal, Bergvik, \& Wynn, 2018). However, it is also significant to explore and identify the factors that will enable girls stay in schools in rural Bangladesh (Amin, Ahmed, Saha, Hossain, \& Haque, 2016). This paper focuses on the collective function of socio-cultural gender norms, patriarchal society and economic deprivation, which are factors behind dropout of high school girls in rural Bangladesh.

\section{Literature Review}

\section{The context of girls' education in Rural Bangladesh}

Economists suggest that in order to achieve sustainable development goals, the developing countries should invest heavily in women's education (Glick, 2008). Consequently the World Bank and other development organizations, along with respective governments have been facilitating programs (with fund) that support economically struggling school girls in developing countries (Bareq, 2018; Patrinos \& Psacharopoulos, 2020). Bangladesh currently has two programs that provide financial incentives for girls to attend school (Mousumi \& Kusakabe, 2020). In primary education the Food for Education Program is given to both girls and boys, but the secondary School Scholarship Program is designed and implemented only for girls (Baulch, 2011; Mousumi \& Kusakabe, 2020). This programme supports girls with a small monthly stipend for attending secondary school regularly. However, the progress of the govt. funded programmes is less effective among socially and economically disadvantaged girls from rural areas (Del Franco, 2010; Begum, Sharmin, Hossain, Yeasmin \& Ahmed, 2017). Rural areas have the worst health condition (Hahn, Islam, Nuzhat, Smyth, \& Yang, 2018), low literacy level, and the highest number of cases of dropout of high school girls (Del Franco, 2010).

Bangladeshi society is patriarchal where women face challenges imposed by socio-cultural gender norms, which obstructs women from getting power and resources, forces women to be subordinated to men in public and private matters (Au, Nourin, \& Ahmed, 2021). Socio-cultural gender norms function along with other significant structural factors, such as economic deprivation, rural environment and customs to limit women's access to formal education and economic opportunities (Halim, 2020; Jayachandran, 2021). Unlike male students, female students are unreasonably expected to perform most of the domestic chores and responsibilities, they have very limited social mobility, and they are expected to remain chaste until marriage (Psaki, S. R., 2015). Parents have primary, and in most cases absolutely, decision-making power about their female children including their marriage and education (Hoang, 2011). Eventually these socio-cultural gender norms strengthen discrimination against young girls, and encourage child marriage. 


\section{Theoretical Background}

In this article, social norm theory and gender theory have been applied to analyze the factors behind girls' high school dropout in the context of Bangladesh. The social, cultural, and economic structural factors function in complex ways to influence family members and people in general to take decisions about their girls/daughters future education. Using qualitative data from rural high school girls, we intend to apply social norms theory and gender theory to decipher a better understanding of the reasons of girls' school dropout.

\section{Social Norm Theory}

Social norm theory has been applied to analyze and understand the reasons and nature of the imposition of socio-cultural expectations on individuals; and how it influence girls and woman' lives. This theory evolves in defining social norms as social, cultural and traditional beliefs that people internalize and uphold about the code of conduct of men and women according to the expectation of social culture and tradition. What men and women should do or be; and what others expect them to do or be. In any society individuals are expected to comply with social norms for certain reasons: family pressure, pressure from relatives, secured gender identity, for social and cultural expectations (Keleher \& Franklin, 2008). Individuals feel the pressure of being judged according to the standard of sociocultural norms that they are expected to compliance with (Rudman, \& Glick, 1999; Mackie, Moneti, Shakya \& Denny, 2015). Social norms theory provides an effective framework to analyze the sociocultural expectations from a girl, and how these norms restrict their opportunities; and function behind girls' school dropout.

\section{Gender Theory}

The concept of gender is a socially and culturally constituted 'multi-structured system or institution' that society believes in and performs at individual and domestic level, at macro level, and at interactional level (Ridgeway, 2009; Risman, 2018). Gender theory emphasizes on the socialization process of people in general, and how they uphold the existing gendered identities and related injustices and inequalities (Marcus \& Harper, 2014). Out of several branches of gender theories, performance theory focuses on symbolic interactionist act of 'doing gender' (West \& Zimmerman, 1987; Alexander, Giesen \& Mast, 2006). This theory focuses on the social and cultural construction of gender, which is not biologically determined. Unlike sex, gender is 'learnt' through everyday practices and performances of individuals when they 'do' or 'perform' gender. By performing and doing gender they participate in creating culturally and socially constructed gender differences between men and women (Lorber \& Martin, 2012). These gender differences are systematically reproduced through social interactions, which are seen as essential and innate nature of male and female genders (Lorber \& Martin, 2012).

This paper applies gender performance theory as a frame work to analyze and understand social segregation between male and female, gender discrimination in domesticity and in social institutions according to different gender performances. Gender performances, along with gender inequality in wage employment, dowry expectations in girls' marriages, wedding expenses in case of girls; and gender discrimination in empowerment (women's non-existent role in household decision making, limited access to and control over resources) also limit girls' opportunities in life (Field \& Ambrus, 2008; Talukder, Hasan, Razu, \& Hossain, 2020).

\section{Method}

In this paper we adopt, a qualitative case study, designed to investigate gender socialization in the context of rural Bangladesh through in-depth interviews with five respondents. This paper analyzes the interaction between the socio-cultural gender norms, domestic and economic condition of each respondent that have significant influence on girls' dropout from secondary school. 


\section{Data collection and sampling}

The design of data collection method was purposive. Five adolescent high school dropout girls were selected from two different schools from two villages (fasiatala, golartek) under Dhaka division, Bangladesh. The sampling of the respondents was purposive; based on age, academic status and socioeconomic status of their family.

\section{Data collection}

Two rounds of in-depth interviews were conducted with the respondents to reach out their experiences as deep as possible. Two introductory meetings were also conducted before the main interview sessions. The first introductory meeting was held to explain the study to the respondents; and to obtain written consent from their parents. The second meeting was held to explain the interview questions, and counsel the respondents regarding sharing their past traumatic and sensitive experiences. After getting positive consent from the respondents, the main interview was conducted in a place of their individual choices; which was mostly their respective houses. The interviews were conducted maintaining absolute privacy; without any interferences from parents or other family members. Special care and attention was given to the respondents while discussing sensitive personal and family issues which helped to reveal the reasons for dropping out of school. Apart from discussing their personal experiences, the respondents were also engaged in discussing school dropout and early marriage among their friends, classmates, and sisters to attain an in-depth detailed discussion on the main topics. All interviews were audio-recorded, transcribed verbatim and then translated into English. All translated transcripts were reviewed against the digital audio files for further accuracy. To protect their privacy, we refrained from using their actual names throughout the paper.

\section{Analysis and Findings}

After the first-round of interview, important themes regarding the socio-economic background of the families (parents' social and economic status), educational, career and marital status of the respondents and their other siblings were identified. Semi-structured interview questions were proved to be helpful to make the respondents comfortable with the discussion sessions. Five main themes emerged out of the interview sessions: 1. Economic status regulates parents' decisions; 2. Socio-cultural gendered norms regulate parents' decisions; 3. Parents impose patriarchal decisions - lack of healthy communication with parents; 4. Marriage is seen as the best establishment for girls; 5. Expected household responsibilities from girls.

Thematic and narrative analyses have been combined while analyzing data. The thematic coding was put into primary themes; and detailed subthemes were added to it. Memos were written during coding to make the comparison more effective in interpreting data; and drawing inferences. Personal details were discussed and constructed across both rounds of interviews. An incorporation of narrative analysis seemed to be effective to consider each cases to understand the depth of details in data.

\section{Profile of the respondents}

All five respondents come from a very humble socio-economic background. Their parents are not educated and most of them have more than two siblings. The demographic profile shows two of the respondents were already married at the age of 17 and 18. All of them dropped out of high school at grade 8 and 9 .

Table 1: The demographic details of the six respondents

\begin{tabular}{lcllll}
\hline $\begin{array}{l}\text { Respondents } \\
(\mathbf{R})\end{array}$ & Age & $\begin{array}{l}\text { Family } \\
\text { background }\end{array}$ & Siblings & Married/unmarried & $\begin{array}{l}\text { Dropping } \\
\text { grade }\end{array}$ \\
\hline R-1 & 17 & Farmer & $\begin{array}{l}2 \text { brothers, 1 } \\
\text { sister }\end{array}$ & Unmarried & Grade 9 \\
R-2 & 17 & Small & 2 brothers, 1 & Unmarried & Grade 8 \\
\hline
\end{tabular}


DOI: https://doi.org/10.47405/mjssh.v6i8.962

\begin{tabular}{lcllll}
\hline R-3 & 16 & $\begin{array}{l}\text { entrepreneur } \\
\text { Vegetable }\end{array}$ & $\begin{array}{l}\text { sister } \\
3 \text { sisters } \\
\text { vendor }\end{array}$ & Unmarried & Grade 9 \\
R-4 & 18 & $\begin{array}{l}\text { Caretaker at } \\
\text { school }\end{array}$ & $\begin{array}{l}\text { 2 brothers, 1 } \\
\text { sister } \\
\text { Small }\end{array}$ & Married & Grade 9 \\
R-5 & 17 & Married & Grade 9 \\
\hline
\end{tabular}

\section{Case studies}

\section{Case 1 - Respondent-1}

Respondent-1 is from a farmer's family from fasiatala, Dhaka. Her father did not want her to continue her study because he did not have enough money to support all three children. She was forced to drop out of school at $9^{\text {th }}$ grade. Her father is supporting her brother's vocational education. Her parents want to marry her off before she turns 20 years old. R-1 recalls:

I was forced to drop out. I cried a lot. Abba (father) only supports bhai (brother). Now I help my mother with household chores. I do not want to get married, but my parents will force me again. If I do not listen to them then everyone will call me a derailed, bad girl. My parents fear if I go to school I will have an affair with a boy; which parents will never allow.

The quote reveals R-1's fear for being labeled as a bad girl according to the standard of socialgendered norms. There is a social pressure for girls to remain good in the eye of the society. She feels the emotion of sadness and deprivation because she was forced to drop out. She has mentioned about her brother being supported by her father with financial assistance, which brings out the persistent practice of gender discrimination within Bangladeshi household. She is burdened with household chores, and she has also expressed her fear of being married off against her will.

\section{Case 2 - Respondent- 2}

Respondent-2 has two brothers and one sister. Her father is a small entrepreneur. She was a good student, but because of the financial condition of the family she was forced to quit school because her parents want her to help her mother in household chores and in raising her young brother. Her parents think they have to save money to marry her off; so they do not want to spend further on her education.
I like to study, my results were good. But my parents do not want me to attend school anymore. I cried to go to school, but my father scolded me. He said we need a lot of money for my marriage. They cannot spend on my education. My youngest brother is small, parents want me to take care of him. I do not want to get married now. Abba (father) says I will be derailed if I am not married early.

Respondent -2 was a good student, but she had to quit school because she was expected to help in household chores, take care of the youngest brother. This indicates the indirect training she was expected to receive from her mother regarding household chores and raising a child. Parents do not hesitate to judge the character of their female child and consider marriage the only solution to protect the girl. She has also added:

My parents say girls will go to their in law's house and will not take any responsibility of her parents. But boys will be with them in the old days and that is why they should invest on their education. I feel sad, I do not want to get married. I want to study. I did not want to drop out, but my father was angry and he also beat me up. He thinks I am a burden. 
Gender discrimination is obvious in their family. Boys are trusted and preferred for the interest of the parents and their family. Her quote reveals that girls are victim of domestic and social violence. Her experience reveals how a girl's aspiration and desires are being suppressed; and parent's decisions are being imposed on the girl.

\section{Case 3 - Respondent- 3}

Respondent -3 studied in her village school in till $5^{\text {th }}$ standard. She went to the neighbouring village golartek to attend high school as there is no high school for girls in their village. She had to stay with her maternal grandmother's house with other aunts, uncles and cousins. It was difficult for her to stay there away from parents and two younger sisters. However she still wanted to stay there and study as her grandmother was bearing her education expenses. But her parents made her quit school and brought her back home because she was caught having an affair with one of her older cousin's friends. She mentioned:

I was lonely in my grandmother's house because everyone was much older than me and busy with their own works. I was happy in my relationship with my boyfriend, but their family is rich and they were against our relationship. His father threatened my father and asked him to take me back home. I cried a lot, did not want to come back. My father is very stubborn and suspects my character; he even beat me up. Now they fixed my wedding with a much older already married man who is rich. I wanted to commit suicide, but I have two younger sisters. I have to think about them, their life. I am the eldest.

Respondent-3 had emotional difficulties to share her painful story with us. We had to organize several interview sessions to make her comfortable enough to talk about the traumatic experiences of her life. Her quote reveals that she had to face traumatic experiences from different people and families. She was very lonely in her grandmother's house, her boyfriend's father humiliated her family for their poor economic condition; and her own father forced her to quit school. She is also a victim of domestic violence. The forced arranged marriage with an old man against her wish led her to the thought of committing suicide. She is also expected to be responsible towards her younger sisters and her family as she is the eldest.

\section{Case 4 - Respondent- 4}

Respondent - 4 had to marry within a short notice of two days when she was only seventeen years old, studying in standard eight. Her father's friend sent a proposal to her house and her parents agreed because they thought marriage was the best establishment for a girl. The groom was much older than her. They did not ask for any dowry because the girl is beautiful. She has also mentioned that her parents intend to invest on their sons' education. Respondent-4 states:

The most traumatized day of my life was my wedding day. I was so scared. Please do not tell my husband or my parents. I had to leave school, my friends, and teachers. My parents thought marriage was the best thing for me. They will support my brothers' education, but not mine. My parents trust my brothers. My education is a burden for them. I have to think about my youngest sister. My parents want me to act responsible as I am the eldest daughter in the family.

This quote indicates a forced and imposed wedding on a seventeen years old girl, injected fear about her husband and parents, her sense of loss and sadness for dropping out of school. Lack of trust from parent's side, gender discrimination inside the family, and an imposed responsibility for being the eldest daughter made her feel miserable and helpless. 


\section{Case 5 - Respondent-5}

Respondent-5 is the second eldest among five sisters. She and her eldest sister both are married. They have no brother, so her parents wanted to marry off the elder sisters as early as possible. They were looking for stable families who can give the girls financial stability, and can also help their parents in need of any financial support. The eldest sisters have responsibility of taking care of the younger sisters. But parents never thought of educating their daughters, giving them a chance to earn money. They thought only well-off husbands can be good for the daughters and their family. Respondent-5 describes:
My eldest sister was smart, intelligent and a good student. But my parents married her off when she was only fifteen years old. Her husband is financially stable. My brother in law's friend married me. My husband is 12 years older than me. I am not happy with him, but I do not have any choice. My brother in law and my husband gave money to my father to invest in our farm land. My father depends on our husbands a lot. I cried when I was forced to quit school. I wanted to become a teacher. My dreams are all shattered. My parents think we five sisters are burdens. Relatives always say they worry about my father. Our society is hypocritical, does not give chance to a girl to prove herself, to be independent. But easily blames her for being a burden.

The experiences of the respondents are similar in cases of financial deprivation of the families, forced marriages, responsibilities of household chores, and the responsibilities towards younger siblings. Respondent-5 describes how her parents wanted financially stable husbands for the daughters rather than expecting the daughters to be educated and financially stable. Financial instability, in some cases extreme poverty, is used as a reason for early marriages for the girls. Bangladeshi social norms do not give girls an opportunity to be financially independent; rather they are encouraged to be dependent on fathers and husbands.

Table 2: Summary of Themes

\begin{tabular}{ll}
$\begin{array}{l}\text { Number of } \\
\text { Themes }\end{array}$ & Emerging new themes \\
\hline Theme 1 & $\begin{array}{l}\text { Economic status regulates parents' decisions } \\
\text { Theme } 2\end{array}$ \\
Theme 3 & $\begin{array}{l}\text { Socio-cultural gendered norms regulate parents' decisions } \\
\text { Parents impose patriarchal decisions - lack of healthy communication with }\end{array}$ \\
Theme 4 & $\begin{array}{l}\text { Marriage is seen as the best establishment for girls } \\
\text { Theme } 5\end{array}$ \\
\hline
\end{tabular}

\section{Theme -1 Economic status regulates parents' decisions}

All the respondents come from humble family background. When parents have financial instability or crisis they stop financing their girls' education. Girls are forced to drop out of school when parents encounter economic deprivation. However they continue financing the boys because they are believed to be the bearer of the family name. Girls are expected to support their parents' families with the help of their husband's money. As respondent two and three have mentioned: "Economic instability, financial crisis or poverty" have been major reasons behind their parents' decision of taking girls out of school.

\section{Theme - 2 Socio-cultural gender norms regulate parents' decisions and their treatment towards girl children}

Respondents stressed on the influence of socio-cultural gender norms on the decision making process of their parents, and on their treatment towards their girl children. It has been seen in the girls' 
experiences that parents judge their girl children according to the socio-cultural gender norms. If the girl is seen with a boy or male friends she is instantly termed as a girl with bad a character. If a girl enters into a romantic relationship with a boy/man she is scolded, beaten up, suspected of losing virginity or getting unwarrantedly pregnant. Parents harbour fear that girls might degrade the honour of their family. A girl's character is always under severe scrutiny. Her own parents, relatives, and society believe that marriage is the only way to unburden the pressure that parents feel to protect their daughters.

\section{Theme - 3 Parents impose patriarchal decisions - lack of healthy communication with parents}

In this particular context, the parents of the respondents are not educated. They do not consider their daughters' opinion about their lives. Girls are not allowed to take any decision whether to go to school, to continue study, to get married or not, to choose their own life partner or not; to work and be financially independent or not. They are expected to submissively obey all decisions, about their lives, taken by their parents; mainly by their fathers. In most cases, parents do not encourage any healthy discussion with their girl children where they can put forward their aspirations and opinions. It is quite claustrophobic for them because they are denied to express their aspirations, dreams and opinions.

\section{Theme - 4 Marriage is seen as the best establishment for girls}

Interestingly, in Bangladeshi society, marriage is seen as the only solution for a permanent settlement of a girl. If a girl's parents are having a financial crisis they look for a well off husband for the girl; and expect that groom to not only take care of their daughter but also to help her parents financially. If parents find a girl in a romantic relationship, they will soon arrange a marriage with any random man they find suitable, against the girl's wish. If a girl is being stalked or harassed by derailed boys/men, parents would look for a suitable groom who can give shelter and protection to their daughter.

\section{Theme - 5 Expected household responsibilities}

In Bangladeshi society, girl children are expected to take the major responsibility of household chores. They are expected to be trained in cooking, cleaning, raising younger siblings, and taking care of the elderly members in the family. The boys of the family are not expected to learn any household chores, and they are never expected to take care of their younger siblings. Sometimes boys help their fathers in their farmland or in their shops; but hardly are they expected to learn or do cooking, cleaning or washing.

\section{Discussions}

This qualitative study analyses the factors behind high school dropout of girls in rural Bangladesh. The findings reveal how poor economic condition and discriminatory gendered social norms function together to influence parents to take their daughters out of school. Data has shown that parents become scared of their daughter's chastity and purity ever since they hit puberty. Social prejudices and discrimination influence parents' attitude towards the daughters; and in the name of safety daughters are usually kept inside house. Data also reveals that daughters are not encouraged to study more, to get established or learn any skill to be self-dependent. Being influenced by gendered biased social norms, families only suggest marriage as the only solution for girls. Marriages are also seen as a protective measure taken to keep girls' chastity and character safe. All the respondents have mentioned that their parents do/did not allow them to have any affair or relationship with any boy/man. Girls in rural areas are not allowed to keep male friends. Purdah (veil) is strictly expected to be maintained by girls. Gender norm theory helps to analyze the girl's situation within a discriminated domestic setup and in the society. 
Findings of the study also show that families engage girls in household responsibilities including maintaining the house to raising younger siblings. On the other hand, findings also reveal that families invest on boys' education because social norms suggest that boys will take care of the parents in their old age. The study connects financial deprivation and gendered social norms to girls' dropout of high school. Parents tend to compromise with girl's education first if they have to impose financial sanction in domesticity.

Two married respondents have identified their problems with the social norms of judging women based on their chastity or purity. Parents get influenced by the traditional social idea of keeping girls safe only by marrying them off as soon as they reach puberty. Traditional gendered social norms generate fear in parents about the chastity of a menstruating daughter. Sometimes girls face psychological fear, pressure and shame about the social humiliation of being labelled as a bad girl if she is no married early. Two of the respondents $(R-4, R-5)$ who were married left school because of that. To change social norms and practices regarding gender, child marriage and girls' education parents and guardians have to resist socio-cultural gender norms to bring positivity in girls' lives so that they become skilled, confident and independent. It would be wise to link families to government schemes that provide stipends, scholarships, and other incentives to support girls' retention in school. A collective effort from families, leaders in the communities, village communities, school management committees, policy makers and implementers can break through social norms and practices regarding gender, child marriage and girls' education.

\section{Limitations}

The study focuses only on respondents from the families that have economic deprivation and who live in rural Bangladesh. High school dropouts from financially stable families would have added more perspectives to the study. Only two married girls took part in the study. Participation of more married girls could have brought out more findings about the connection between early marriage and school dropout.

\section{Conclusion}

The paper intends to have implication in modification of socio-cultural gendered norms and perspectives towards girls/women' education to bring gender equality. Govt. needs to develop and implement more effective policies to ensure economic stability and better education for the girls living in poverty. Better policies are needed to facilitate girls, from vulnerable families, the opportunity to finish high school. The paper intends on having positive effect on the necessity of promoting more gender balanced, gender sensitive, equal and aspirational progressive gender norms to create better opportunities for girls, and to generate healthy environment for both the genders. The paper would be encouraging for analyzing more on how education enhances the opportunities of well-being, and ensure empowerment of women.

\section{References}

Aboud, F. E. (2007). Evaluation of an early childhood parenting programme in rural Bangladesh. Journal of health, population, and nutrition, 25(1), 3.

Aikman, S., \& Rao, N. (2012). Gender equality and girls' education: Investigating frameworks, disjunctures and meanings of quality education. Theory and Research in Education, 10(3), 211228.

Alexander, J. C., Giesen, B., \& Mast, J. L. (Eds.). (2006). Social performance: Symbolic action, cultural pragmatics, and ritual. Cambridge University Press. 29-74

Amin, S., Ahmed, J., Saha, J., Hossain, M., \& Haque, E. (2016). Delaying child marriage through community-based skills-development programs for girls: Results from a randomized controlled study in rural Bangladesh. New York and Dhaka: Population Council. 
Au, W. C., Nourin, S., \& Ahmed, P. K. (2021). The unfolding process of womens entrepreneurship in a patriarchal society: an exploration of Bangladeshi women entrepreneurs experiences. In Women's Entrepreneurship and Culture. Edward Elgar Publishing.

Bareq, A. (2018). The Role of World Bank as a Development Partner in Bangladesh: A case study of Education Sector (Doctoral dissertation, University of Dhaka). http://repository.library.du.ac.bd:8080/bitstream/handle/123456789/1448/Abdul\%20Bareq.pdf?

Bates, L. M., Maselko, J., \& Schuler, S. R. (2007). Women's education and the timing of marriage and childbearing in the next generation: evidence from rural Bangladesh. Studies in Family Planning, 38(2), 101-112.

Baulch, B. (2011). The medium-term impact of the primary education stipend in rural Bangladesh. Journal of Development Effectiveness, 3(2), 243-262.

Bernard, H. R. (2017). Research methods in anthropology: Qualitative and quantitative approaches. Rowman \& Littlefield.

Bilkis, S. (2015). Girls' education and empowerment: impact of secondary level schooling on rural women's lives in Bangladesh (Doctoral dissertation, University of Dhaka).

Chisamya, G., DeJaeghere, J., Kendall, N., \& Khan, M. A. (2012). Gender and Education for All: Progress and problems in achieving gender equity. International journal of educational development, 32(6), 743-755.

Del Franco, N. (2010). Aspirations and self-hood: exploring the meaning of higher secondary education for girl college students in rural Bangladesh. Compare, 40(2), 147-165.

Ferdousi, N. (2014). Child marriage in Bangladesh: Socio-legal analysis. International Journal of Sociology and Anthropology, 6(1), 1-7.

Field, E., \& Ambrus, A. (2008). Early marriage, age of menarche, and female schooling attainment in Bangladesh. Journal of political Economy, 116(5), 881-930.

Glick, P. (2008). What policies will reduce gender schooling gaps in developing countries: Evidence and interpretation. World Development, 36(9), 1623-1646.

Guglielmi, S., Jones, N., Muz, J., Baird, S., Mitu, K., \& Uddin, M. A. (2020). I Don't Have Any Aspiration Because I Couldn't Study": Exploring the Educational Barriers Facing Adolescents in Cox's Bazar. Policy Brief. London: Gender and Adolescence: Global Evidence.

Halim, S. (2020). Women's Ownership Rights and Access to Land in Bangladesh. In Women, Land \& Power in Asia (pp. 87-102). Routledge India.

Heissler, K. (2011). 'We are poor people so what is the use of education?' Tensions and contradictions in girls' and boys' transitions from school to work in rural Bangladesh. The European Journal of Development Research, 23(5), 729-744.

Herz, B., Herz, B. K., \& Sperling, G. B. (2004). What works in girls' education: Evidence and policies from the developing world. Council on foreign relations.

Hoang, L. A. (2011). Gender identity and agency in migration decision-making: Evidence from Vietnam. Journal of Ethnic and Migration Studies, 37(9), 1441-1457.

Hunt, F. (2008). Dropping Out from School: A Cross Country Review of the Literature. Create Pathways to Access. Research Monograph, No. 16. UK: University of Sussex

Islam, M. R., \& Mia, A. (2007). The role of education for rural population transformation in Bangladesh. International Journal of Work-Integrated Learning, 8(1), 1.

Jayachandran, S. (2021). Social norms as a barrier to women's employment in developing countries. IMF Economic Review, 1-20.

John, N. A., Stoebenau, K., Ritter, S., Edmeades, J., Balvin, N., \& Unicef. (2017). Gender socialization during adolescence in low-and middle-income countries: Conceptualization, influences and outcomes.

Kabeer, N. (2011). Between affiliation and autonomy: navigating pathways of women's empowerment and gender justice in rural Bangladesh. Development and change, 42(2), 499-528.

Keleher, H., \& Franklin, L. (2008). Changing gendered norms about women and girls at the level of household and community: a review of the evidence. Global Public Health, 3(S1), 42-57.

Latif, A., Usman, A., Ali, S., \& Amjad, A. (2020). Effects of area of residence, education level and wealth of reproductive-aged woman on child's nutritional status: Evidence from Multiple Indicator Cluster Survey (MICS) 2011. Rawal Medical Journal, 45(1), 176-178.

Lorber, J., \& Martin, P. Y. (2012). The socially constructed body. Illuminating social life: Classical and contemporary theory revisited, 249. 
Mackie, G., Moneti, F., Shakya, H., \& Denny, E. (2015). What are social norms? How are they measured. University of California at San Diego-UNICEF Working Paper, San Diego. USA: New York.

Mahmud, S., \& Amin, S. (2006). Girls' schooling and marriage in rural Bangladesh. In Children's lives and schooling across societies. Emerald Group Publishing Limited.

Mahumda, M. (2019). Causes of girl's pupil dropout at secondary school in Bangladesh: Review of literature and empirical analysis (Master's thesis, Universitetet i Agder; University of Agder).

Marcus, R., \& Harper, C. (2014). Gender justice and social norms-processes of change for adolescent girls. London: Overseas Development Institute.

Mousumi, M. A., \& Kusakabe, T. (2020). School education system in Bangladesh. Handbook of Education Systems in South Asia, 1-36.

Namuliira, P. (2020). Family planning adolesencents' sexual behavior and female labor force participation in Uganda (Doctoral dissertation, University of Dar es Salaam).

Nations, U. (2015). Transforming our world: The 2030 agenda for sustainable development. New York: United Nations, Department of Economic and Social Affairs.

Parveen, S. (2007). Gender awareness of rural women in Bangladesh. Journal of International Women's Studies, 9(1), 253-269.

Psaki, S. R. (2015). Addressing early marriage and adolescent pregnancy as a barrier to gender parity and equality in education. Background paper for the.

Ramsdal, G. H., Bergvik, S., \& Wynn, R. (2018). Long-term dropout from school and work and mental health in young adults in Norway: A qualitative interview-based study. Cogent Psychology, 5(1), 1455365.

Ridgeway, C. L. (2009). Framed before we know it: How gender shapes social relations. Gender \& society, 23(2), 145-160.

Risman, B. J. (2018). Gender as a social structure. In Handbook of the Sociology of Gender (pp. 1943). Springer, Cham.

Rudman, L. A., \& Glick, P. (1999). Feminized management and backlash toward agentic women: the hidden costs to women of a kinder, gentler image of middle managers. Journal of personality and social psychology, 77(5), 1004.

Sarkar, R. K., Reza, M. M., \& Hossain, M. E. (2014). Socio Cultural Barriers of Girls' Educational Attainment Experiences From Rural Bangladesh. Cultural Anthropology, 10(2), 349-358.

Sarker, M. N. I., Wu, M., \& Hossin, M. A. (2019). Economic effect of school dropout in Bangladesh. International Journal of Information and Education Technology, 9(2), 136-142.

Sarker, S. I., Karim, A. H. M., \& Suffiun, S. M. A. (2017). Parental educational aspiration and gender inequality of rural children in Bangladesh: the role of parental attitudes of traditional gender role, gender biased capability, and gender. Journal of International Women's Studies, 18(2), 134-142.

Schuler, S. R. (2007). Rural Bangladesh: Sound policies, evolving gender norms, and family strategies. Exclusion, Gender and Education: Case Studies from the Developing World. Washington, DC: Center for Global Development, 179-204.

Schuler, S. R., Bates, L. M., \& Islam, F. (2008). Women's rights, domestic violence, and recourse seeking in rural Bangladesh. Violence against women, 14(3), 326-345.

Schurmann, A. T. (2009). Review of the Bangladesh female secondary school stipend project using a social exclusion framework. Journal of health, population, and nutrition, 27(4), 505.

Shah, S., \& Shah, U. (2012). Girl education in rural Pakistan. Revista Internacional de Sociología de la Educación, 1(2), 180-207.

Shahidul, S. M. (2012). Marriage market and an effect on girls' school dropout in Bangladesh. Journal of Alternative Perspectives in the Social Sciences, 4(2), 552-564.

Svanemyr, J., Moland, K. M., Blystad, A., Zulu, J. M., \& Sandøy, I. (2021). Norms and sexual relations among adolescents in the context of an intervention trial in rural Zambia. Global Public Health, 1-13. doi.org/10.1080/17441692.2021.1947343

Talukder, A., Hasan, M. M., Razu, S. R., \& Hossain, Z. (2020). Early marriage in Bangladesh: a crosssectional study exploring the associated factors. Journal of international women's studies., 21(1), 68-78. 
DOI: https://doi.org/10.47405/mjssh.v6i8.962

Varga, C. A. (2003). How gender roles influence sexual and reproductive health among South African adolescents. Studies in family planning, 34(3), 160-172.

Warrington, M., \& Kiragu, S. (2012). "It makes more sense to educate a boy": Girls 'against the odds' in Kajiado, Kenya. International journal of educational development, 32(2), 301-309.

West, C., \& Zimmerman, D. H. (1987). Doing gender. Gender \& society, 1(2), 125-151. 